\title{
Activity and composition of the benthic fauna in the Whittard Canyon and the adjacent continental slope (NE Atlantic)
}

\author{
Gérard DUINEVELD*, Marc LAVALEYE, Eilke BERGHUIS, Peter de WILDE
}

Department of Marine Ecology, Netherlands Institute for Sea Research, P.O. Box 59, 1790 AB Den Burg Texel, The Netherlands

Received 30 May 2000; revised 5 October 2000; accepted 10 October 2000

\begin{abstract}
We compared the sediment and its community on the Celtic continental slope (Goban Spur) with those in a branch of the nearby Whittard Canyon in search for evidence of canyon mediated transport of (labile) organic matter. We studied the megabenthos and macrobenthos biomass and taxonomic composition, measured in situ sediment community oxygen consumption and determined sediment concentrations of particulate organic carbon, phytopigments, and nucleic acids. While the sediment community and activity on the canyon fan was similar to that on the abyssal station near Goban Spur, the sediment within the canyon had relatively enhanced sediment community oxygen consumption rates and higher levels of phytopigments, particulate organic carbon and nucleic acids, particularly towards the canyon head. However, near-bottom sediment traps and transmissometre readings gave no sign of enhanced particle fluxes. Most likely this enrichment is supplied periodically through lateral transport as suggested by increased numbers of filter-feeding macrobenthos. Markedly higher concentrations of sedimentary pigments were found in a second branch of the Whittard Canyon illustrating the complexity of canyon systems and the need for a much more extensive study. (C) 2001 Ifremer/CNRS/IRD/Éditions scientifiques et médicales Elsevier SAS
\end{abstract}

Résumé - Activité et composition de la faune benthique dans le canyon de Whittard et la pente continentale celtique voisine. Nous avons comparé le sédiment et sa communauté de la pente continentale celtique (Goban Spur) avec ceux d'une branche du canyon voisin de Whittard, pour mettre en évidence le transport relatif de matière organique (labile) par le canyon. Nous avons étudié la biomasse et la composition taxonomique du megabenthos et du macrobenthos, mesuré la consommation d'oxygène in situ de la communauté sédimentaire, et déterminé les concentrations de carbone organique particulaire, des pigments végétaux et des acides nucléiques. Alors que la communauté sédimentaire et l'activité au pied du canyon sont similaires à la station abyssale près de Goban Spur, le sédiment du canyon présente une consommation d'oxygène plus élevée, et des concentrations supérieures de pigments végétaux, de carbone organique particulaire et d'acides nucléiques, particulièrement vers la tête de canyon. Cependant, les données des pièges à particule et les mesures de transmission près du fond n'indiquent pas un rehaussement du flux de particules. Cet enrichissement périodique est dû au transport latéral, comme l'indiquent les densités supérieures de macrobenthos à régime alimentaire de filtreurs. Des concentrations de pigments nettement plus élevées ont été trouvées dans une deuxième branche du canyon de Whittard, ce qui illustre la complexité des systèmes de canyon et la nécessité d'une étude beaucoup plus approfondie. () 2001 Ifremer/CNRS/IRD/Éditions scientifiques et médicales Elsevier SAS

deep-sea / canyon / macrofauna / metabolism / phytopigments

zone abyssale / canyon / macrofaune / métabolisme / pigments végétaux

*Correspondence and reprints: fax: +31 222319674 .

E-mail address: duin@nioz.nl (G. DUINEVELD).

(C) 2001 Ifremer/CNRS/IRD/Éditions scientifiques et médicales Elsevier SAS. Tous droits réservés 


\section{INTRODUCTION}

The export of organic carbon from productive continental shelves to deep waters has been under debate for considerable time (Walsh et al., 1981; Walsh et al., 1988; Wollast, 1998). During the SEEP-I studies (Walsh et al., 1988) on the United States Atlantic continental margin, evidence was found for accumulation of carbon on the mid slope. Associated with this carbon depocenter, high rates of sediment community oxygen consumption were measured (Rowe et al., 1994). The subsequent SEEP-II studies (Biscaye et al., 1994) showed the mid-slope carbon-deposit to be fuelled by relatively refractory carbon. More recently a similar study was conducted on the continental margin SW of Ireland, i.e. the Ocean Margin Exchange (OMEX) program (Van Weering et al., 1998). In this program evidence for off shelf transport was sought along a transect over the Goban Spur (figure $1 B)$, which has a gently sloping upper part (200-1500 m) and a steep lower part (1500-3600 m). The OMEX-I results, indeed, yielded indications for a lateral transport to a depth of 1500-2000 m, but a depocenter with a high carbon content and elevated sediment community oxygen consumption rate, as on the NW Atlantic slope was not found (Duineveld et al., 1997; Lohse et al., 1998).

Beside particle transport across a normal slope like the Goban Spur, transport through the numerous steep canyons intersecting the NE European continental margin (figure 1A) forms an alternative route for organic material export from shelf to deep-sea. Several studies have shown that submarine canyons can acts as trap and conduit of organic matter to greater depths which is paralleled by higher benthic or pelagic biomass in the canyon compared to the surrounding area (Rowe et al., 1982; de Bovée et al., 1990; Soetaert et al., 1991; Maurer et al., 1994; Sardà et al., 1994; Gage et al., 1995; Soetaert and Heip, 1995; Macquart-Moulin and Patriti, 1996; Vetter and Dayton, 1998).

In the present study we searched for evidence of transport of organic matter through the Whittard Canyon, it being one of the major canyons of the Celtic margin. Apart for its size the Whittard Canyon was also selected as target area because it is relatively well known from the sedimentological study of Reid and Hamilton (1990) and because of its proximity to our previous OMEX study sites on the Goban Spur. During a cruise to the outer branch and fan of the Whittard Canyon and the Goban Spur we measured a set of variables that mirror organic

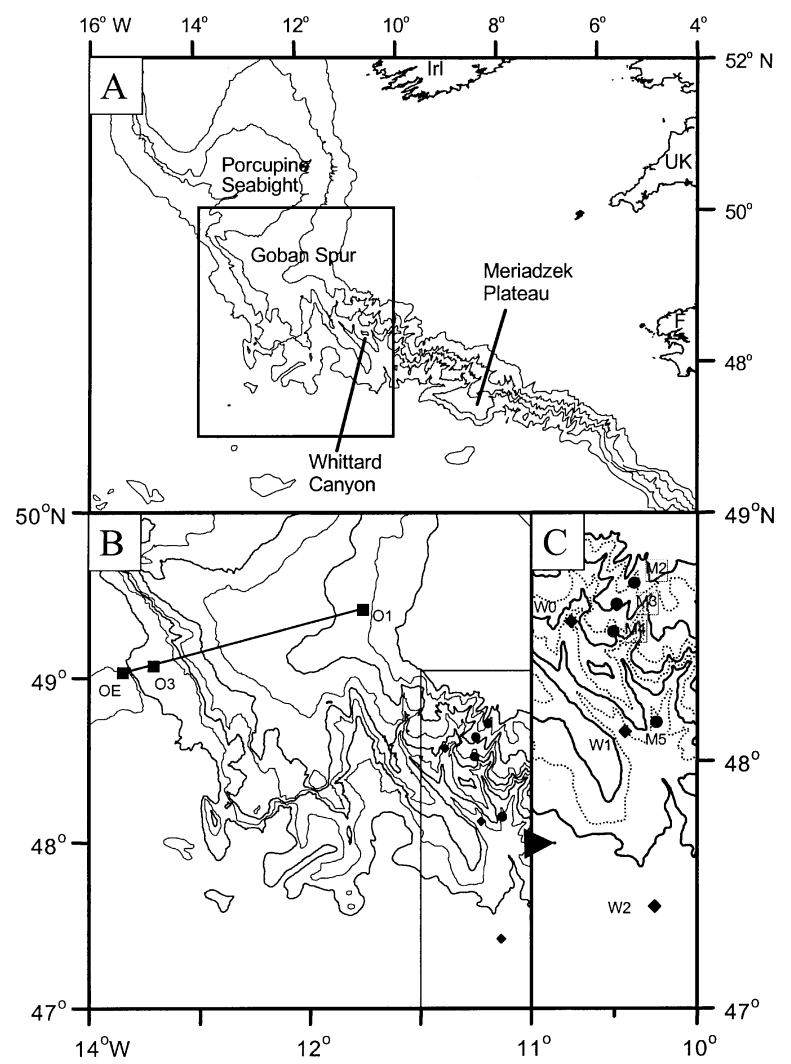

Figure 1. Map of the Celtic continental margin with the samplingstations indicated. A. Position of working area (inset). B. Goban Spur transect (stations $\mathrm{O} 1, \mathrm{O} 3, \mathrm{OE}$ ) and the adjacent Whittard stations (details in C). C. detail of Whittard Canyon showing the sampling stations (W0, W1, W2) in the west branch, and the RV Meteor stations (M2, M3, M4, M5) in the east branch.

matter supply over time scales of different length. The longest time scales are represented by the large benthic mega- and macrofaunal organisms (Flach and Heip, 1996). Variables spanning much shorter time scales were nucleic acids as proxy for biomass of microbial organisms (Dell'Anno et al., 1998) and chlorophyllous pigments as proxies for input of fresh phytodetritus (Stephens et al., 1997). We finally measured in situ sediment community oxygen consumption reflecting mineralization activity of the bacterial community. On the basis of a comparison between the values of these variables measured in the Whittard Canyon and the Goban Spur we discuss the probability of canyonmediated transport of labile organic matter. 
Table I. Stations visited during the cruise with RV Pelagia and the RV Meteor expedition in 1996.

\begin{tabular}{lllll}
\hline Station & Depth $(\mathrm{m})$ & Date & Latitude N & Longitude W \\
\hline O1 & 660 & $20-21 / 07$ & $49^{\circ} 24.67^{\prime}$ & $11^{\circ} 31.79^{\prime}$ \\
O3 & 3600 & $30 / 07$ & $49^{\circ} 04.18^{\prime}$ & $13^{\circ} 25.24^{\prime}$ \\
OE & 4500 & $28 / 07$ & $49^{\circ} 01.92^{\prime}$ & $13^{\circ} 41.79^{\prime}$ \\
W0 & 2735 & $26 / 07$ & $48^{\circ} 33.54^{\prime}$ & $10^{\circ} 45.55^{\prime}$ \\
W1 & 3760 & $22-23 / 07$ & $48^{\circ} 06.97^{\prime}$ & $10^{\circ} 25.97^{\prime}$ \\
W2 & 4375 & $24 / 07$ & $47^{\circ} 24.47^{\prime}$ & $10^{\circ} 15.27^{\prime}$ \\
M2 & 804 & $26 / 08$ & $48^{\circ} 42.90^{\prime}$ & $10^{\circ} 22.70^{\prime}$ \\
M3 & 1506 & $27 / 08$ & $48^{\circ} 37.90^{\prime}$ & $10^{\circ} 29.40^{\prime}$ \\
M4 & 2303 & $28 / 08$ & $48^{\circ} 30.90^{\prime}$ & $10^{\circ} 30.10^{\prime}$ \\
M5 & 3699 & $29 / 08$ & $48^{\circ} 09.20^{\prime}$ & $10^{\circ} 15.00^{\prime}$ \\
\hline
\end{tabular}

See geographical position in figure 1 .

\section{MATERIAL AND METHODS}

\subsection{Site description}

The Whittard Canyon is situated on the Celtic margin between the Goban Spur and the Meriadzek Terrace (figure 1). The canyon system extends from the upper slope down onto the abyssal plain. The upper part of the canyon is a complex system of smaller canyons and valleys. The fan of the canyon is also branched (Reid and Hamilton, 1990). At the upper part, the width of the canyon falls to $700 \mathrm{~m}$, with the side walls attaining a height of $800 \mathrm{~m}$. Towards the abyssal plain the height of the side walls drops to about $100 \mathrm{~m}$ (Reid and Hamilton, 1990). Three stations (W0, W1 and W2; see figure 1C) were sampled in July 1996 with RV Pelagia (NIOZ). Station W1 in the west branch and W2 on the fan are close to stations sampled by Reid and Hamilton (1990). Station W0 is located in the upper part of the west branch. For comparative purposes we revisited three former OMEX stations (O1, O3, OE; see figure $1 B)$ on the Goban Spur with depths comparable to the Whittard stations. Finally, we analysed phytopigments in some additional samples from a second (east) branch of the Whittard Canyon (M2, M3, M4, M5; see figure 1C), which was visited during a cruise with RV Meteor in August 1996 (L. Thomsen, personal communication). Table I summarizes the geographical positions and depths of the stations.

Reid and Hamilton (1990) showed that the mean grain size and sand content in the Whittard Canyon fan decreases down-slope, whilst the carbonate and mud content increases. Near bottom currents measured by them showed a strong tidal sequence. They found a maximum current speed of $16 \mathrm{~cm} \mathrm{~s}^{-1}$ (mean: $6 \mathrm{~cm} \mathrm{~s}^{-1}$ ) at their shallowest station $(3725 \mathrm{~m})$. The orientation of the currents was generally long-slope over the fan part but showed a tendency to run parallel with the axis of the canyon at a shallower station were the canyon is more pronounced.

\subsection{Sediment sampling and analysis}

Cores of $10 \mathrm{~cm}$ diameter for the analyses of sediment phytopigments, organic carbon and grain size were either collected with a multiple corer or extracted from $50 \mathrm{~cm}$ diameter box-core samples. Box-core samples were collected with a corer equipped with a tightly sealing top valve to secure collection of in situ bottom water and to prevent flushing. Replicate sub-cores were taken from different box-core samples. Sediment cores were sliced after carefully slurping the surface millimetre with a syringe. The slices, i.e. 1-5, 5-10, 10-20, 20-30, $30-50 \mathrm{~mm}$, were homogenized, deep-frozen in liquid nitrogen and stored at $-80^{\circ} \mathrm{C}$. Prior to analyses, samples were lyophilised (Smith et al., 1996). Because of analytical constraints, we processed a maximum of three subcores per station. Phytopigments were analysed by means of reverse phase HPLC with photodiode array detection. For details see Duineveld et al. (1997). Nucleic acid concentrations in the sediment samples were measured with HPLC using a Nucleogen ${ }^{\circledR}$ column and absorbance detector $(260 \mathrm{~nm})$. Absorbance peaks were converted into weights using standards of calf thymus desoxyribonucleic acid (DNA) (Merck) and ribosomal ribonucleic acid 
(RNA). For further details see Dell'Anno et al. (1998). The organic carbon content was measured in a Carlo Erba $\mathrm{CHN}$ analyzer. Prior to analysis, inorganic carbon (carbonate) was removed with $\mathrm{HCl}$. The grain size distribution was analysed with a Malvern Particle Sizer 3600 EC.

\subsection{Sediment oxygen uptake}

Measurements of whole sediment community oxygen consumption were made in situ with a free-falling benthic lander (BOLAS; figure 2). BOLAS was equipped with duplicate $30 \mathrm{~cm}$ diameter flux chambers and two singlecup sediment traps $\left(150 \mathrm{~cm}^{2}\right)$ which were closed by a top valve during descent and rise (see details in Tahey et al., 1996). The valves opened $1 \mathrm{~h}$ after the landing of BOLAS. A video system mounted on the lander showed that any disturbance effects had ceased within an hour after the lander had reached the sea floor. To avoid the risk of a collision with the canyon sidewall at station W1, we lowered the lander with the ship's cable to a position fifty metres above the sea floor from where it was released by means of an acoustic command.

On the Whittard stations we made microprofiles of the porewater oxygen content in decompressed sediment cores (multi-corer) to determine the maximum oxygen penetration depth. For this purpose we used a Diamond ${ }^{\circledR}$ microelectrode (tip $20 \mu \mathrm{m}$ ) mounted in a NIOZ-built microprofiler (step-size $0.1 \mathrm{~mm}$ ). The profiles were made at in situ temperature.

\subsection{Macro- and megafauna sampling}

Macro-infauna were collected with a $50 \mathrm{~cm}$ diameter box-corer. The samples were gently washed over nested 1.0 and $0.5 \mathrm{~mm}$ sieves. Residues were preserved in $4 \%$ buffered formaldehyde until laboratory processing. Only one sample per station was analysed. For the calculation of macrofauna biomass we adopted an arbitrary upper 'size' limit for macrofauna of $50 \mathrm{mg}$ wet weight, to prevent bias by single large organisms (Duineveld et al., 1997). Polychaetes were identified to family level, the remaining macrofauna was identified to higher taxonomic categories. Individual biomass was measured as blotted wet weight with an accuracy of $0.1 \mathrm{mg}$. Wet mass was converted to ash free dry weight and carbon using existing conversion factors (Rowe, 1983).

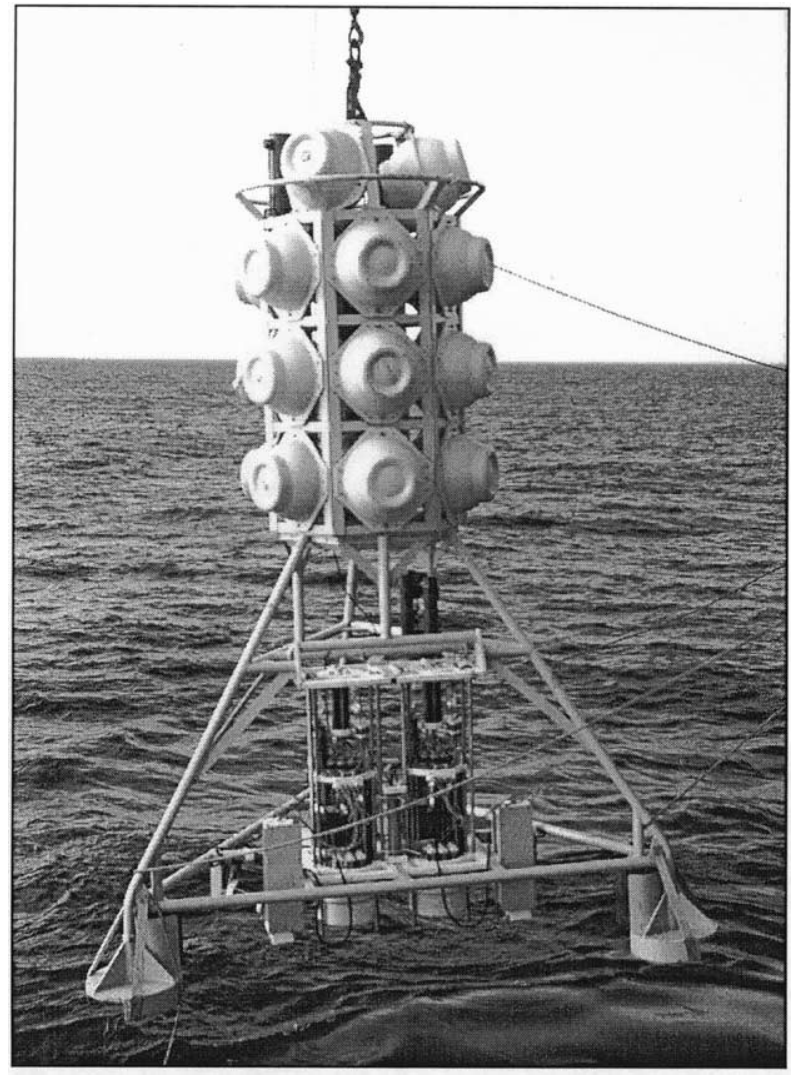

Figure 2. Free-falling BOLAS lander equipped with two $30 \mathrm{~cm}$ diameter incubation chambers.

Sometimes a considerable part of the organisms that we collected on the $1.0 \mathrm{~mm}$ and $0.5 \mathrm{~mm}$ sieves consisted of large branched agglutinated foraminiferans. Because the tubes tend to break up very easily during sieving, we took two sub-cores $\left(100 \mathrm{~cm}^{2}\right.$ each) from the surface of two box-core samples and preserved the top $2 \mathrm{~cm}$ in formaldehyde without sieving. Because we still had problems with accurately counting individual foraminiferans, we subsequently measured the total surface area covered by the pieces as a relative measure of abundance.

Megafauna were collected using an Agassiz trawl with an opening of $1 \mathrm{~m}$ height and $3.5 \mathrm{~m}$ width and a net with a mesh size of $1 \mathrm{~cm}$. A mechanical trap closes the trawl opening during descent and rise. The trawl was further equipped with two odometre wheels $(1 \mathrm{~m})$ and a remote video system. Because we used a lightweight Super Aram ${ }^{\circledR}$ cable for trawling, a weight of $750 \mathrm{~kg}$ was 
inserted between the end of the ships cable and the $500 \mathrm{~m}$ steel leader attached to the beam of the trawl. We estimated the effective trawl distance by combining and comparing the readings from the odometre wheels, the recordings of the video camera and the tension gauge. In the laboratory the taxonomic composition of the trawl samples was studied, whereby all organisms were counted and weighed as blotted wet weights. Trawling at station W0 was impossible because of the irregular surface of the canyon floor.

\section{RESULTS}

\subsection{Sediment community oxygen consumption}

We were able to make four lander deployments, at W1, $\mathrm{W} 2, \mathrm{O} 3$ and OE. All measurements except for the one at $\mathrm{W} 1$ gave comparable oxygen consumption rates of about $0.6 \mathrm{mmol} \mathrm{O}_{2} \mathrm{~m}^{-2} \mathrm{day}^{-1}$. At $\mathrm{W} 1$, however, we found an in situ rate, which was twice as high i.e. $1.3 \mathrm{mmol} \mathrm{O}_{2} \mathrm{~m}^{-2}$ day $^{-1}$. The higher metabolic activity of the sediment at W1 compared to $\mathrm{W} 2$ is congruent with the reduced sediment penetration depth of oxygen at the former station measured in shipboard incubated cores. Maximum oxygen penetration depths at W1 (and W0) varied between 2.6 and $3.7 \mathrm{~cm}$ while at $\mathrm{W} 2$ penetration depths exceeded $5 \mathrm{~cm}$ (figure 3). The increase of the maximum penetration depth is consistent with a lower oxic mineralization rate (Lohse et al., 1998). Glud et al. (1994) showed that the interfacial oxygen gradient in decompressed deep-sea cores may become affected by heating and bacterial lysis during ascent. For this reason we refrained from calculating diffusive flux rates on basis of interfacial gradients and hence only report the maximum oxygen penetration depth, which we assume would be more robust and thus better reflect relative differences in organic matter mineralization.

\subsection{Sediment grain size, and carbon nitrogen content}

The grain-size distribution in the surface centimetre was more or less the same at the three canyon stations with a silt percentage $(<50 \mu \mathrm{m})$ between 95 and $98 \%$ (figure 4 ). At W0 the upper $10 \mathrm{~cm}$ of the sediment seem to be more or less homogeneous, perhaps only with slightly coarser

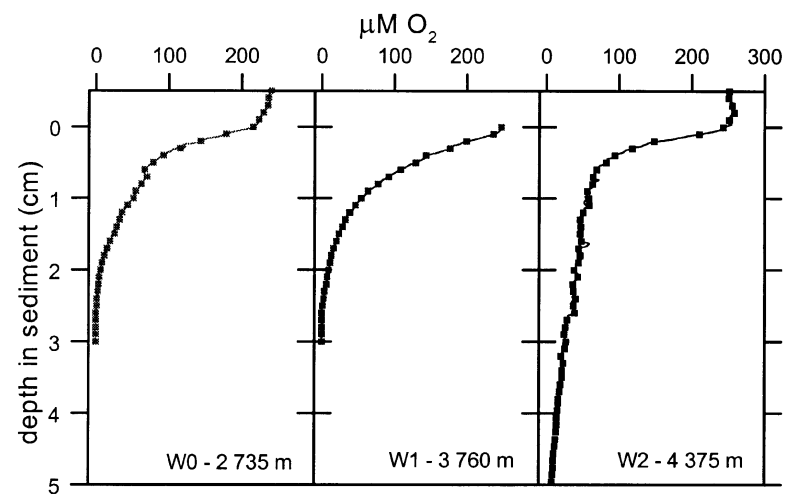

Figure 3. Microprofiles of the porewater oxygen concentration measured in decompressed sediment cores from stations W0, W1 and W2.

sediment at $10-11 \mathrm{~cm}$ depth. At W1 and W2, however, we found a distinct layer of coarse material deeper in the cores. At station W2 further out on the Whittard fan this layer is clearly manifest below the upper centimetre and consists of very fine to fine sand with the percentage silt dropping to $35 \%$. At $\mathrm{W} 1$ the coarse layer appears to be thinner and silt percentage attains surface values again at $10 \mathrm{~cm}$ depth. The $\mathrm{CaCO}_{3}$ content of all surface sediments collected in the canyon was relatively low in comparison to the sediment from the Goban Spur indicating a higher supply of terrestrial sediments (figure 5). In accordance with Reid and Hamilton (1990) highest $\mathrm{CaCO}_{3}$ content was found at W2, which is consistent with an increasing marine input with growing distance from the slope. We have no further data that can explain the presence of the subsurface layer of fine sand at W2, which stands in apparent contrast with growing marine input. Possibly this layer represents a turbidity deposit which is covered by a thin layer of marine sediments.

The organic carbon content $(P O C)$ in the upper centimetres at the Whittard stations is clearly higher, i.e. $0.9-1.1 \%$, than in the surface sediments of the OMEX stations, i.e. $0.4-0.5 \%$ (figure $6 A$ ). At W0 high POC levels persists down core to $5 \mathrm{~cm}$ but at the other canyon stations $\mathrm{W} 1$ and $\mathrm{W} 2$ the POC content $2-3 \mathrm{~cm}$ below the surface drops to levels comparable to the Goban Spur cores (figure 6A). This drop, however, could be partially due to the coarser material that we found at depth in the core since carbon content and grain size have a well known inverse relationship. A similar pattern as for $P O C$ is also found for the nitrogen content (figure 6B). The $\mathrm{C}: \mathrm{N}$ 


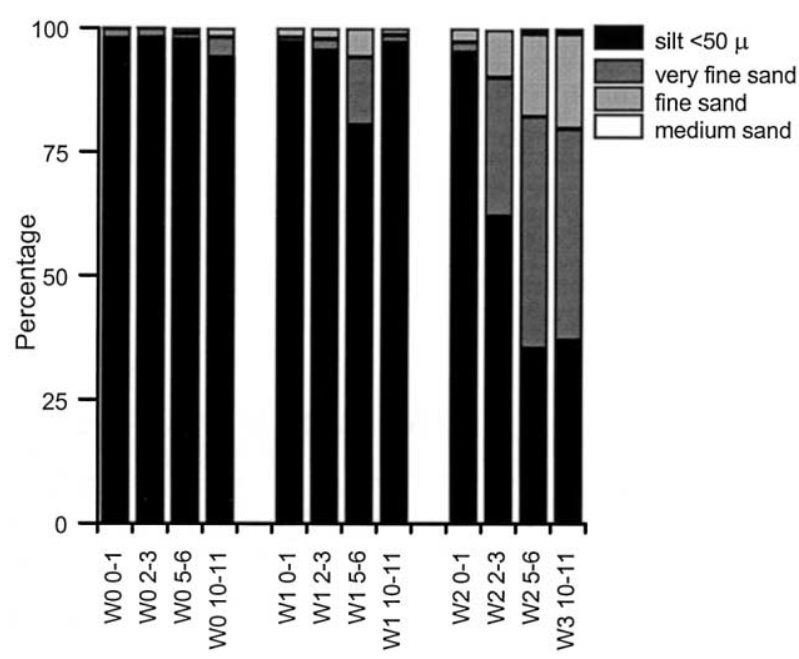

Figure 4. Grain size distribution of the sediment at the three canyon stations.

values in both sample series fall for most part into a rather narrow range with the extremes being W2 having relatively high (9-13) and OE with low (5-6) ratios. The C:N ratios at the other stations varied between 8 and 9 .

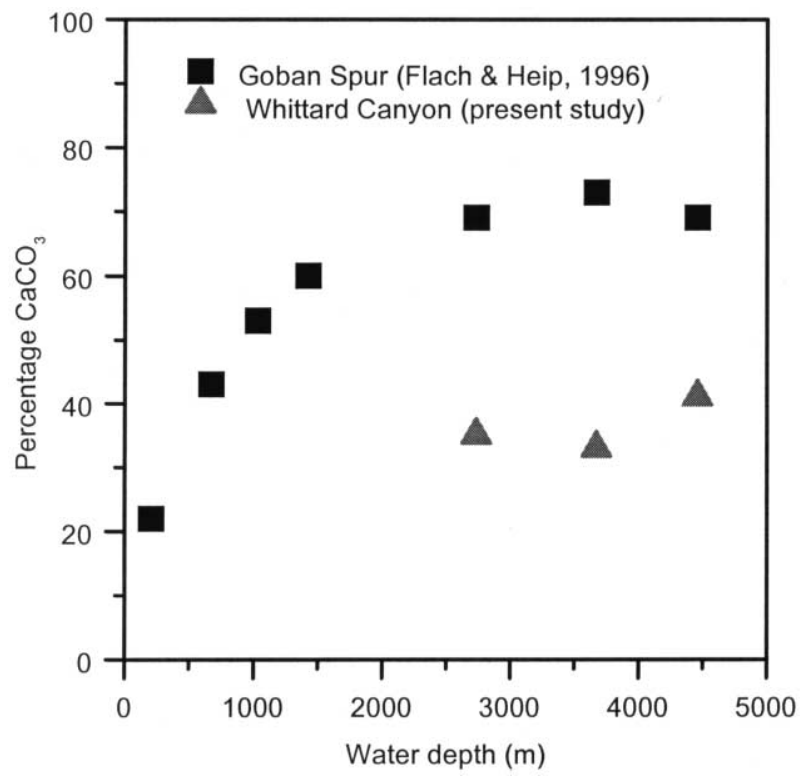

Figure 5. The $\mathrm{CaCO}_{3}$ content in the surface sediment of the canyon stations compared with data from the OMEX stations (Flach and Heip, 1996), in percentage of sediment dry weight.

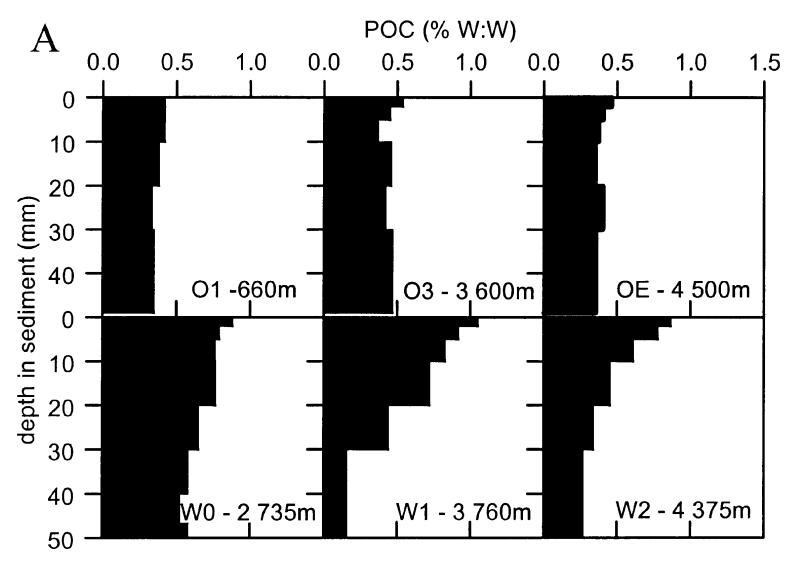

B

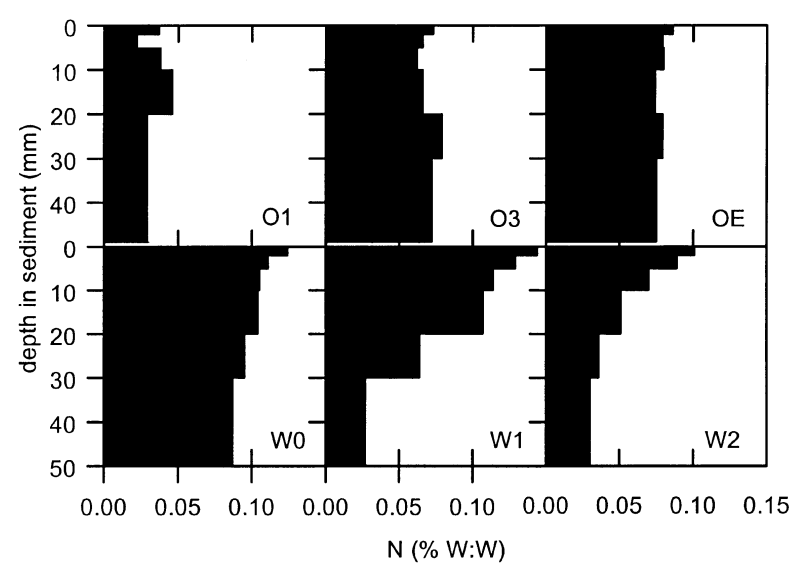

Figure 6. Down-core concentrations (in $\% \mathrm{w} / \mathrm{w}$ ) at three Whittard Canyon stations and three Goban Spur stations. A. Particulate organic carbon. B. Nitrogen.

\subsection{Phytopigments}

Variation in recent phytodetritus input among the stations is illustrated by means of the pigment concentrations in the upper $5 \mathrm{~cm}$ (figure 7). We have concentrated on chloropigments (chlorophyll $a$ and derivatives) because the number and levels of intact carotenoid pigments were quite low. One of the few identifiable carotenoids in the sediment samples was peridinin, which is a marker pigment of dinoflagellates. Furthermore traces of fucoxanthin were found which is a pigment occurring in many algal classes. In the majority 

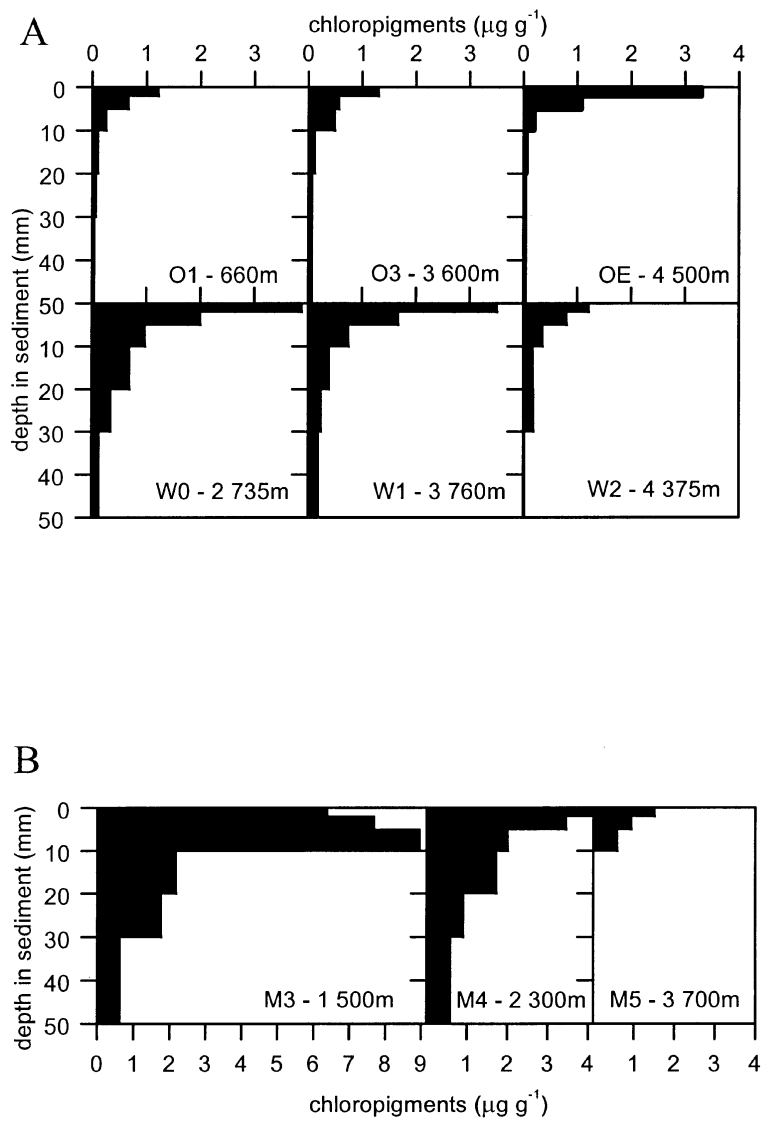

Figure 7. Down-core distribution of chloropigments (in micrograms per gram). A. In cores collected with RV Pelagia at the open continental slope (Goban Spur) and the west branch of the Whittard Canyon. B. In cores taken with RV Meteor from a second (east) branch of the Whittard Canyon (see figure 1 .

of the cores, chloropigment concentrations decreased sharply within the upper centimetre, i.e. by a factor of five to ten, indicating a rapid degradation (see figure $7 A$ ). The chloropigments mainly consisted of phaeophorbides and to a lesser extent phaeophytins. Chlorophyll $a$ accounted on average for about $5 \%$ (range $3.4-6.3$ ) of the total chloropigment pool.

Surprisingly, the shallowest station (O1) on the upper slope had relatively the lowest concentration of chloropigments in the surface centimetre $0.17 \pm 0.08 \mu \mathrm{g} \mathrm{g}^{-1}$ (weighted mean $\pm \mathrm{SD}$ ). Levels in the sediment at the lower slope and rise of the Goban Spur (stations O3 and OE) were somewhat higher, $0.20 \pm 0.06$ and $0.28 \pm 0.18 \mu \mathrm{g} \mathrm{g}^{-1}$ respectively but not quite as high as the two stations within the canyon, i.e. W0 and W1, where concentrations of $0.45 \pm 0.18$ and $0.47 \pm 0.17 \mu \mathrm{g} \mathrm{g}^{-1}$ were found. Station W2 on the Whittard fan again had much lower pigment levels, $0.20 \pm 0.11 \mu \mathrm{g} \mathrm{g}^{-1}$, close to those at corresponding depth on the Goban Spur transect (OE).

Much higher concentrations of phytodetritus were found in cores from stations M3 and M4 located in the east branch of the Whittard Canyon (figure 1C), which yielded mean concentrations of $2.55 \pm 1.70$ and $2.90 \pm 0.30 \mu \mathrm{g} \mathrm{g}^{-1}$ respectively. These cores did not only have high concentrations in the upper centimetre but elevated levels in the deeper layers as well (figure 7B). At station M3 $(1506 \mathrm{~m})$ with the highest concentration of chloropigments (figure 7), intact chlorophyll $a$ was still detectable at $7 \mathrm{~cm}$ depth (not shown). This situation clearly contrasts with cores from the other stations in which chlorophyll $a$ invariably dropped below detection level within the upper few centimetres and only degradation products persisted.

\subsection{Nucleic acids}

We measured total extractable DNA and RNA in the upper centimetre of the Whittard and Goban Spur cores as proxies for total microbial biomass (DNA) and metabolically active biomass (RNA) respectively. Figure $8 \mathrm{~A}$ shows the average concentrations of DNA and RNA in the upper centimetre being the weighted mean of values \pm SD for the $0-2,2-5$ and $5-10 \mathrm{~mm}$ slices. DNA levels at $1 \mathrm{~cm}$ were about $50 \%$ of the surface values while RNA levels dropped to less than $25 \%$, reflecting the sharp reduction in metabolic activity (figures $8 B, C$ ). Concentrations of DNA at the Whittard stations W1 and W2 were comparable to those at Goban Spur stations O3 and OE i.e. range $21.6-29.8 \mu \mathrm{g} \mathrm{g}^{-1}$. The sediment of canyon station W0 had a clearly elevated DNA concentration, $45.6 \pm 5.1 \mu \mathrm{g} \mathrm{g}^{-1}$, while the shallow upper slope station O1 similarly as with chloropigments had lowest DNA concentrations $16.5 \pm 1.4 \mu \mathrm{g} \mathrm{g}^{-1}$. Concentrations of RNA in the canyon sediments are on average higher than the ones on the Goban Spur (figure 8A). Likewise as with DNA the shallowest canyon station W0 had the highest RNA level i.e. $10.5 \pm 3.1 \mu \mathrm{g} \mathrm{g}^{-1}$ and upper slope station $\mathrm{O} 1$ the lowest $3.4 \pm 0.3 \mu \mathrm{g} \mathrm{g}^{-1}$. When compared to previous (unpublished) data on nucleic acids on the Goban Spur in spring 1994, the present concentrations of DNA and notably RNA at stations O3 and OE (not O1) appear to be higher. While levels of DNA are higher by a factor 

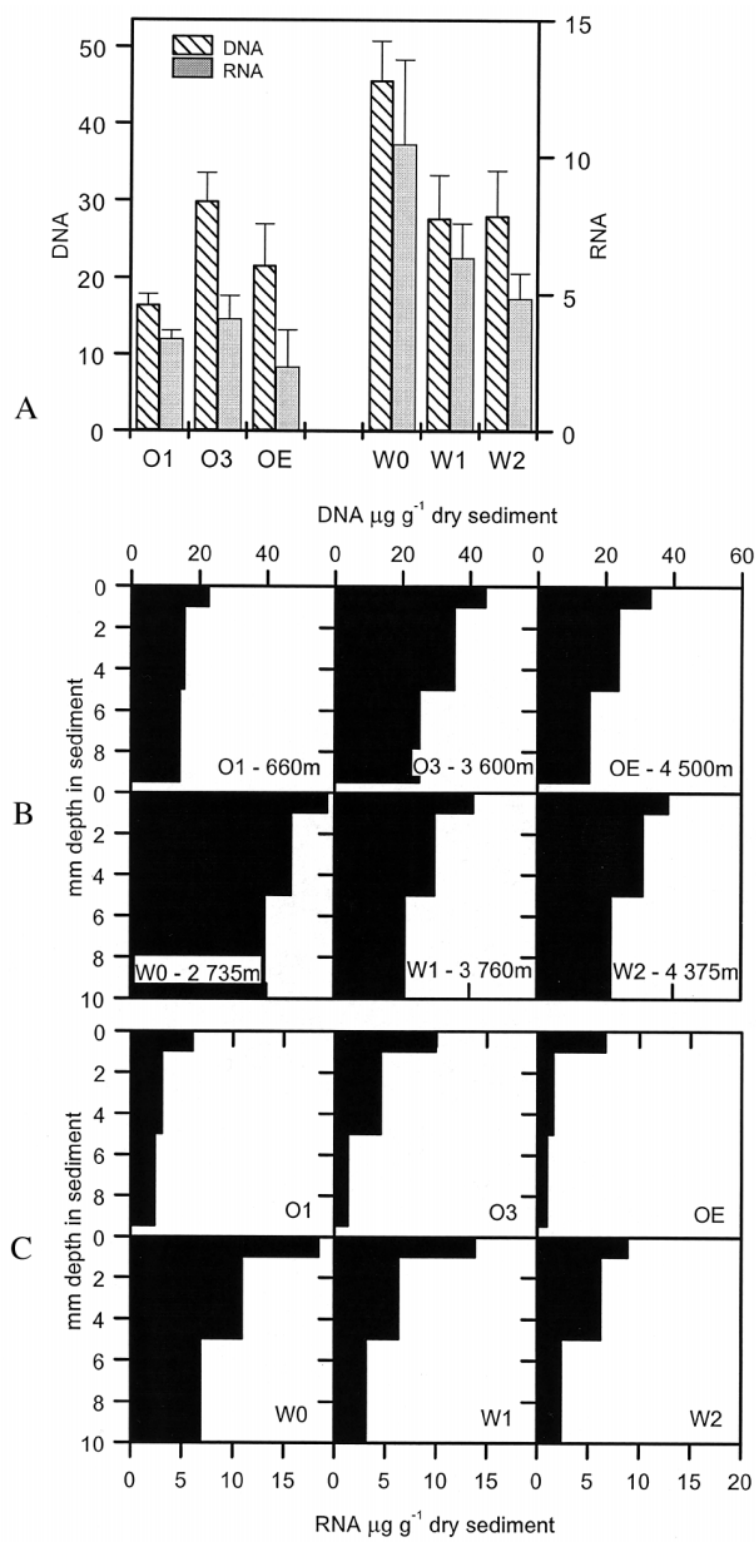

Figure 8. A. Average concentrations of sediment bound DNA (cross hatched bars) and RNA (grey bars) in the upper centimetre of the sediment of cores collected with RV Pelagia at the open continental slope (Goban Spur) and the west branch of the Whittard Canyon. Units are in micrograms per gram sediment and error bars denote the standard deviation. B. Down-core distribution of DNA. C. Down-core distribution of RNA.

of 2, RNA concentrations were higher by a factor of 10 , which could be due to the higher concentrations of phytodetritus.

\subsection{Macrofauna}

Table II compares density and biomass of macrofauna $(>0.5 \mathrm{~mm})$ collected on the Whittard stations in 1996 with data from the Goban Spur collected during previous cruises (Duineveld et al., 1997). Only Goban Spur stations with water depths corresponding to the Whittard stations have been listed. By using earlier data from the Goban Spur we assume that the biomass and gross composition of macrofauna living below mid-slope depths $(\sim 1500 \mathrm{~m})$ are not subject to large year-to-year variations, which is in agreement with findings by Flach and Heip (1996). Because we could only take one core per station in the Whittard Canyon, estimates of total biomass from these single cores tend to become easily confounded by a single large specimen. We, therefore, adopted an upper limit for individual weight of $50 \mathrm{mg}$ and excluded larger individuals from table II. Our data from the Goban Spur in table II fit well within the ranges reported by Flach and Heip (1996) who made a detailed inventory of the macrofauna abundance and biomass during successive years. Likewise as on the Goban Spur, where macrofauna density and biomass show an exponential decrease with water depth (Flach and Heip, 1996), macrofauna standing stock in the canyon decreases with depth or distance from the canyon head. Total macrofauna density at the Whittard stations matches well with the values at the Goban Spur stations found by us (table II) and by Flach and Heip (1996). Macrofauna biomass at the Whittard stations appears to be elevated when compared to stations on the lower slope of Goban Spur (stations OF, O3, OE; table II). The values for the Whittard stations in table II furthermore suggest a decrease of biomass between $\mathrm{W} 0$ and $\mathrm{W} 1$ and less so between $\mathrm{W} 1$ and $\mathrm{W} 2$ despite a difference in density.

Table II. Macrofauna density and biomass (wet weight) on the Goban Spur and the Whittard Canyon.

\begin{tabular}{llll}
\hline Station & $\begin{array}{l}\text { Depth } \\
(\mathrm{m})\end{array}$ & $\begin{array}{l}\text { Density } \\
\left(\text { individuals } \mathrm{m}^{-2}\right)\end{array}$ & $\begin{array}{l}\text { Biomass } \\
\left(\mathrm{mg} \mathrm{m}^{-2}\right)\end{array}$ \\
\hline OF* $^{*}$ & 2200 & 2200 & 3039 \\
O3 $^{*}$ & 3600 & 2420 & 1256 \\
OE* $^{*}$ & 4500 & 807 & 886 \\
W0 & 2735 & 2717 & 4739 \\
W1 & 3760 & 1339 & 1877 \\
W2 & 4375 & 696 & 1592 \\
\hline
\end{tabular}

Data marked with * are from an earlier survey in 1994. 
Table III. Density and biomass of macrofauna for the three Whittard stations.

\begin{tabular}{|c|c|c|c|c|c|c|}
\hline & \multicolumn{2}{|l|}{ W0 - $2735 \mathrm{~m}$} & \multicolumn{2}{|l|}{$\mathrm{W} 1-3760 \mathrm{~m}$} & \multicolumn{2}{|l|}{$\mathrm{W} 2-4375 \mathrm{~m}$} \\
\hline & Density (individuals $\mathrm{m}^{-2}$ ) & $\begin{array}{l}\text { Wet weight } \\
\left(\mathrm{mg} \mathrm{m}^{-2}\right)\end{array}$ & Density (individuals $\mathrm{m}^{-2}$ ) & $\begin{array}{l}\text { Wet weight } \\
\left(\mathrm{mg} \mathrm{m}^{-2}\right)\end{array}$ & Density (individuals $\mathrm{m}^{-2}$ ) & $\begin{array}{l}\text { Wet weight } \\
\left(\mathrm{mg} \mathrm{m}^{-2}\right)\end{array}$ \\
\hline Carnivores & $517(19 \%)$ & $788(17 \%)$ & $76(6 \%)$ & $155(8 \%)$ & $96(14 \%)$ & $394(25 \%)$ \\
\hline Deposit-feeders & $2071(76 \%)$ & $3499(74 \%)$ & $769(57 \%)$ & $1526(81 \%)$ & $549(79 \%)$ & $1054(66 \%)$ \\
\hline Filter-feeders & $129(5 \%)$ & $452(9 \%)$ & $494(37 \%)$ & $195(11 \%)$ & $50(7 \%)$ & $142(9 \%)$ \\
\hline Total & 2717 & 4739 & 1339 & 1877 & 696 & 1592 \\
\hline
\end{tabular}

Numbers in parentheses are percentages of the different feeding types.

The distribution of macrofauna feeding types along the Goban Spur has been reported by Flach et al. (1998). They found that the macrofauna on the lower slope (2200-3700 m) consisted of 20-30\% filter-feeders, while carnivores and deposit-feeders more or less equally shared the remaining percentage. At their deepest station OE, Flach et al. (1998) found an increase of depositfeeders to more than $50 \%$ of the total numbers at the cost of carnivores while filter-feeders (bryozoans, tunicates) accounted for about $30 \%$ of the total. The distribution of feeding types at the Whittard stations is shown in table III. At the canyon station W0 and station W2 on the fan, deposit feeders were the dominant feeding guild in numbers (76-79\%) and biomass (66-74\%) with filterfeeders accounting for less than $10 \%$ of the numbers and biomass. In contrast, at station $\mathrm{W} 1$ the proportion of filter-feeding organisms was relatively high, i.e. $37 \%$. The majority of these filter-feeders at $\mathrm{W} 1$ were tiny sabellid polychaetes occurring in dense patches of up to 33 individuals per $100 \mathrm{~cm}^{2}$ (see also figure 9A). Because of their small size, the Sabellidae contributed little to total biomass and as infaunal carnivores were almost absent, biomass at $\mathrm{W} 1$ is dominated by deposit-feeders just as at the other two stations.

Table IV shows the Bray-Curtis similarity (Bloom, 1981) between macrofauna at the Goban Spur and the Whittard stations. We found a relatively high degree of similarity between station W0 and the mid-slope stations along the Goban Spur notably station OB. Taxa responsible for this association were deposit-feeding polychaetes like Paraonidae, Oligochaeta and burrowing carnivorous polychaetes like Glyceridae. The two other Whittard stations by contrast showed highest similarity to the sample from station OF $(2200 \mathrm{~m})$ situated on the steep Pendragon Escarpment. Apart from similarity to some of the Goban Spur stations, there was a high degree of similarity among the Whittard stations especially between W1 and W2.
Taxa with typically higher density at the Whittard stations were members of the polychaete families Oweniidae and Ampharetidae and the bivalve Malletia.

Branched and agglutinated foraminiferans were a part of the $0.5 \mathrm{~mm}$ sieve residue in every sample we collected at the Whittard stations. As a measure for their abundance we took the percentage cover of the tubes relative to the core surface area. At $\mathrm{W} 1$ and $\mathrm{W} 2$ this percentage was quite small, $<1 \%$ and $2.5 \%$. However, at W0 agglutinated forms were very abundant with coverage of almost $40 \%$.

\subsection{Megafauna and video trawl}

At only one of the Whittard stations (W1), we were successful in making a quantitative haul with the Agassiz trawl. Table $V$ shows total abundance, wet biomass and feeding guilds of the trawl fauna on the Goban Spur and station W1 in 1996, and additionally summarizes results from trawls made in 1995 on the Goban Spur. All trawl samples that we took in 1996 from the lower slope on Goban Spur were numerically dominated by small ophiuroids. This was not the case in August 1995 and we therefore provide two density estimates in table $V$, i.e. with and without ophiuroids.

Megafauna density at $\mathrm{W} 1$ and at the corresponding Goban Spur station O3 were similar in 1996 when small ophiuroids are excluded and this reduced number fits well in the range found below $2200 \mathrm{~m}$ depth on the Goban Spur in the previous year. Total biomass at W1 was clearly higher than at $\mathrm{O} 3$ in 1996 , i.e. $\sim 3$ vs. $0.5 \mathrm{~g} \mathrm{~m}^{-2}$ respectively. This difference was mainly due to few large holothurians (Benthodytes spec.) that we caught at W1. These Benthodytes are also responsible for the high biomass share of deposit-feeders $(99.8 \%)$ at W1. Simi- 


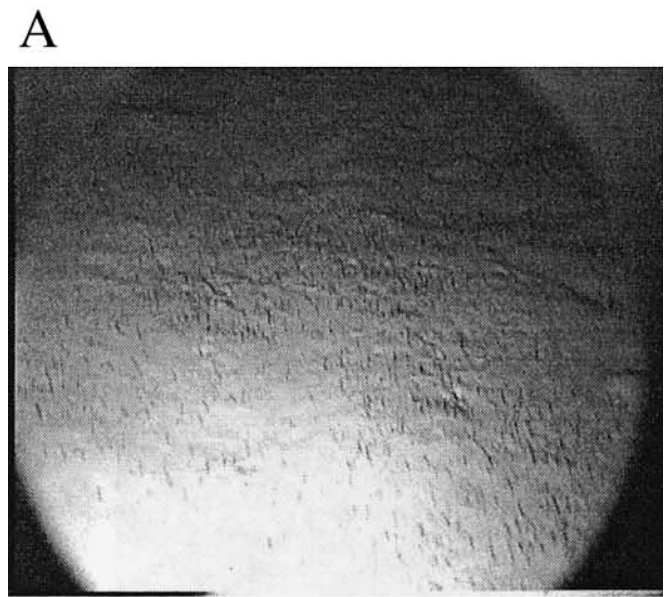

B
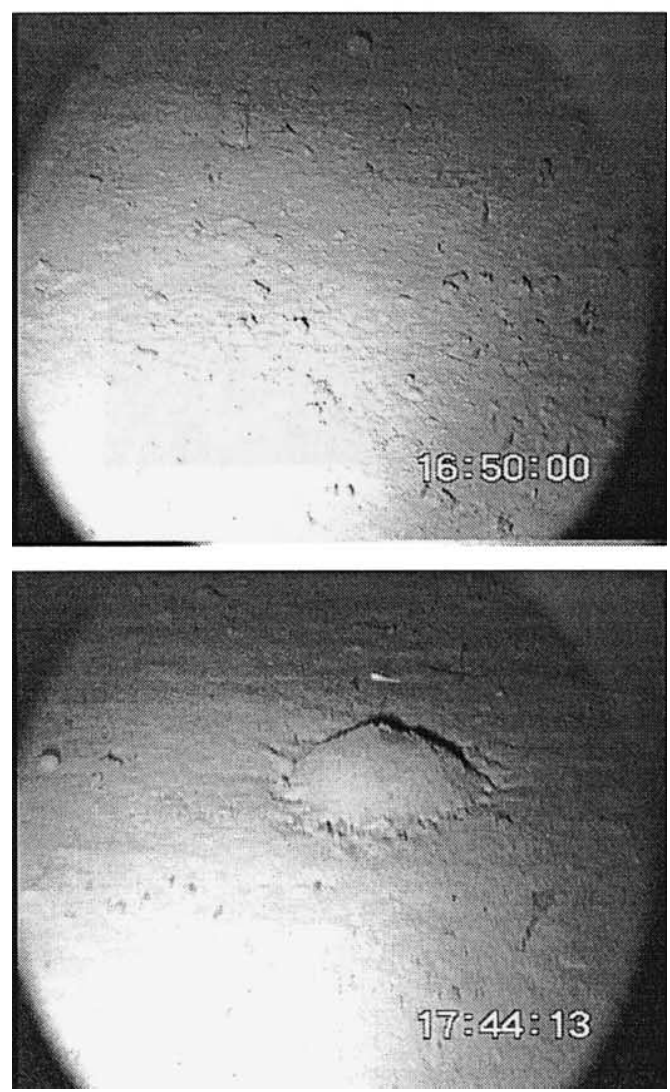

Figure 9. Frames taken from the video trawl in the Whittard Canyon. A. Station W1 $(3760 \mathrm{~m})$ with large numbers of Sabellidae tubes protruding from the sediment. B. Station W2 (4 $375 \mathrm{~m})$ with Xenophyophora (upper frame) and large biogenic structures ('fairy' mounds, lower frame). larly large holothurians (e.g. Psychropotes) were also caught in 1995 at stations $\mathrm{O} 3$ and $\mathrm{OE}$ giving rise to biomass values close to the 1996 value found at W1 (table V) (Duineveld et al., 1997). The biomass comparison between 1995 and 1996 of Goban Spur data in table $V$ clearly indicates large year-to-year differences among the megafauna that were not found with macrofauna.

Video records from Goban Spur station O3 show a primarily flat bottom with scattered large biogenic structures, i.e. mostly 'fairy' mounds with their typical pitted groove (Heezen and Hollister, 1971; Mauviel and Sibuet, 1985) but also higher globular to conical mounds. Besides these large features, the sediment surface is indented with small print and crawl traces suggesting a relatively quiescent environment. The most remarkable features on the video were the numerous small holothurians of a few centimetres length (cf. Amperima) that we saw to be pushed aside by the bow wave of the trawl. This probably explains why we only caught few (badly damaged) specimens in the net whereas the estimate of density from the video amounts to $\sim 20$ individuals $\mathrm{m}^{-2}$. The video records furthermore showed a few traces of large cucumbers and of their faecal deposits. Sessile epifauna like the sea-pen Umbellula were regularly present but scarce. Other incidental occurrences were the anemone Cerianthus, and stalked crinoids. The video from the abyssal Goban Spur station OE likewise showed globular mounds and abundant small sea cucumbers. Furthermore traces as well as live specimens of large sea cucumbers (Oneirophanta, Pseudostichopus, Deima) were seen, some of which were caught by the trawl. Species recorded by video but not caught were the sea anemone Cerianthus and large erect polychaete tubes. Differences between stations OE and O3 were the absence of 'fairy' mounds at $\mathrm{OE}$ and the presence of spoke wheels (Echiura), imprints of star fish, and of long erect polychaete tubes all of which were quite common at OE. Further, the small sea cucumbers (cf. Amperima) were only seen in dense aggregations ( $~ 50$ individuals $\mathrm{m}^{-2}$ ) while at $\mathrm{O} 3$ they were more regularly dispersed.

The short video sequence made at canyon station W1 shows that the sea floor is covered with what looks like remnants of ripple marks. Another striking feature are the numerous small tubes of sabellid polychaetes (see $3.5)$ protruding everywhere from the sediment especially from the ridges of the ripple marks (figure 9A). No 'fairy' nor conical or globular mounds were seen. There were a few crawl tracks and faecal deposits of large sea cucum- 
Table IV. Bray-Curtis similarity between the macrofauna samples from the Goban Spur and the Whittard Canyon.

\begin{tabular}{lrrrrrrrrrr}
\hline Depth $(\mathrm{m})$ & 200 & 700 & 1000 & 1450 & 2200 & 3600 & 4500 & 2735 & 3760 & 4375 \\
\hline & OA & O1 & OB & O2 & OF & O3 & OE & W0 & W1 & W2 \\
OA & 100 & & & & & & & & \\
O1 & 46 & 100 & & & & & & \\
OB & 44 & 64 & 100 & & & & & \\
O2 & 36 & 56 & 63 & 100 & & & & \\
OF & 32 & 46 & 49 & 50 & 100 & & & & \\
O3 & 28 & 40 & 40 & 35 & 54 & 100 & & & \\
OE & 17 & 25 & 26 & 29 & 47 & 35 & 100 & & \\
W0 & 34 & 47 & 56 & 49 & 49 & 38 & 30 & 100 & \\
W1 & 32 & 36 & 40 & 39 & 50 & 39 & 29 & 48 & 100 & 59 \\
W2 & 27 & 39 & 35 & 35 & 53 & 43 & 42 & 50 & 100 \\
\hline
\end{tabular}

Note that most organisms were identified to family or genus level. Data were square root transformed.

bers (Benthodytes). In contrast to the other three stations small sea cucumbers were absent. The sea floor at station W2 on the Whittard fan looks very much like that of Goban Spur station OE, i.e. basically flat with few mounds. Small sea cucumbers were as abundant as at O3, but did not form dense aggregations like at OE. Characteristic for station W2 was the high abundance, $\sim 10$ individuals $\mathrm{m}^{-2}$, of large Xenophyophora (figure $9 B$ ) being sediment agglutinating protozoans (Tendal, 1972). Other noteworthy features were the regular occurrence of large erect polychaete tubes (see OE) and large white scaphopods. Small ophiuroids, common at the Goban Spur stations $\mathrm{O} 3$ and $\mathrm{OE}$, were not seen at $\mathrm{W} 2$.

\section{DISCUSSION}

The significance of down-slope transport of shelf produced particulate matter has been a key issue of a number of multi-disciplinary projects like SEEP-I and II on the US Atlantic margin (Walsh et al., 1988; Biscaye et al., 1994) and recently of the OMEX-I project on the NW European continental margin (Van Weering et al., 1998). Because the labile organic fraction supplied by this transport could be fuel for organisms living in or on the slope sediments, the OMEX-I project included a detailed study of the benthic communities along the slope (Flach and Heip, 1996; Flach et al., 1998). The benthos data

Table V. Estimates of megafauna density, wet biomass and relative significance of the different feeding guilds for stations sampled in August 1996.

\begin{tabular}{|c|c|c|c|c|c|c|c|c|c|}
\hline \multirow[t]{2}{*}{ Station } & \multirow{2}{*}{$\begin{array}{l}\text { Depth } \\
(\mathrm{m})\end{array}$} & \multirow{2}{*}{$\begin{array}{l}\text { Density (individuals } \\
\text { per } 1000 \mathrm{~m}^{-2} \text { ) }\end{array}$} & \multirow{2}{*}{$\begin{array}{l}\text { Weight } \\
\text { (grams per } 1000 \mathrm{~m}^{-2} \text { ) }\end{array}$} & \multicolumn{2}{|c|}{ Deposit-feeders } & \multicolumn{2}{|c|}{ Filter- feeders } & \multicolumn{2}{|c|}{ Carnivores } \\
\hline & & & & $\% \mathrm{~N}$ & $\% \mathrm{~W}$ & $\% \mathrm{~N}$ & $\% \mathrm{~W}$ & $\% \mathrm{~N}$ & $\% \mathrm{~W}$ \\
\hline \multicolumn{10}{|l|}{1996} \\
\hline $\mathrm{O} 1$ & 660 & $640(650)$ & 4347 & 82 & 83 & $\sim 0$ & $\sim 0$ & 18 & 17 \\
\hline W1 & 3760 & 67 (116) & 2950 & 79 & 99 & 4 & $\sim 0$ & 16 & 0.2 \\
\hline $\mathrm{O} 3$ & 3600 & $66(1358)$ & 420 & 98 & 81 & 1 & 1 & 2 & 18 \\
\hline $\mathrm{OE}$ & 4500 & $48(335)$ & 215 & 88 & 88 & 7 & 3 & 4 & 9 \\
\hline \multicolumn{10}{|l|}{1995} \\
\hline OA & 200 & 2477 & 1913 & 87 & 33 & 12 & 38 & 1 & 29 \\
\hline $\mathrm{O} 1$ & 660 & 781 & 1914 & 91 & 57 & $\sim 0$ & $\sim 0$ & 9 & 42 \\
\hline OB & 1000 & 142 & 3180 & 74 & 85 & 2 & $\sim 0$ & 24 & 15 \\
\hline $\mathrm{O} 2$ & 1450 & 132 & 4075 & 55 & 22 & 31 & 70 & 13 & 9 \\
\hline OF & 2200 & 59 & 1188 & 68 & 22 & 11 & 2 & 20 & 76 \\
\hline $\mathrm{O} 3$ & 3600 & 13 & 3789 & 38 & 97 & 11 & $\sim 0$ & 51 & 3 \\
\hline $\mathrm{OE}$ & 4500 & 48 & 2253 & 50 & 98 & 10 & $\sim 0$ & 40 & 2 \\
\hline
\end{tabular}

For comparison, data collected in August 1995 have been included. Numbers in brackets are density estimates including small ophiuroids. 
from the Goban Spur did not point to enrichment anywhere along slope, i.e. total biomass and abundance of meiofauna and macrofauna steadily decreased beyond the upper slope depths and only large megafaunal holothurians seemed to increase in importance at greater depths (Vanaverbeke et al., 1997; Flach et al., 1998). In situ sediment community respiration along the slope showed a comparable continuous decrease with increasing water depth (Duineveld et al., 1997). Similarly, organic carbon burial efficiencies on the Goban Spur were low (Lohse et al., 1998), while the sediment organic carbon content never reached values as high as in the mid-slope carbon depocenter on the US Atlantic slope (Anderson et al., 1994). A straightforward down-slope decrease was also observed in the sediment phytopigment content during the spring bloom. Only in late summer had the sea floor at the lower slope and rise become locally enriched with phytodetritus. This local pulse, however, appeared to be disconnected from the spring bloom input to the upper slope and therefore did not represent export or redistribution (de Wilde et al., 1998). In summary, none of the data on mineralization activity, sediment organic carbon content and benthic biomass supported the hypothesis that the Goban Spur transect was a site of carbon accumulation.

However, in view of the numerous submarine canyons south of the Goban Spur (figure 1A), and observations in submarine canyons elsewhere (Monaco et al., 1990; Maurer et al., 1994; Gage et al., 1995), it seems plausible that the canyons may act as conduits for off-shelf transport of organic material. For this reason we conducted a pilot survey to the Whittard Canyon in search for evidence for this supposition. On the basis of their reconnaissance survey of the Whittard fan, Reid and Hamilton (1990) concluded that fan growth processes are absent and sedimentation is predominantly hemipelagic. Processes which according to Reid and Hamilton (1990) presumably modify the fan morphology at present are slumping and sliding partly caused by slope failure off the continental slope, and erosion and subsequent deposition of fine-grained material by semi-diurnal tides. Though the Whittard system thus seems to be inactive in terms of massive sediment transport it still could act as a site where ephemeral organic material is concentrated and/or funnelled towards the deep-sea. When this would happen on a regular basis, one would expect the sediment composition and especially the longer lived metazoans inhabiting the canyon and adjacent fan to mirror this additional food supply.
The organic carbon content and particularly the pigment concentrations in the surface sediment of the canyon stations (W0, W1) point to organic enrichment in comparison to the Goban Spur. The C:N ratios at $\mathrm{W} 0$ and $\mathrm{W} 1$ being in range of $6-8$ seem to indicate that the carbon pool in the canyon floor is relatively fresh (Flach and Heip, 1996) though similar ratios on the Goban Spur seem to belong to a carbon pool which is mainly refractory in nature (Lohse et al., 1998). Because chloropigments have estimated half lives in deep-sea sediments of the order of only several weeks to months (Stephens et al., 1997; Witbaard et al., 2000) they mark algal matter input on much shorter time scales. The relatively low concentrations of chlorophyll $a$ and of carotenoids on the surface of the canyon floor indicates that the phytodetritus did not represent fresh material from vertical input. The pattern of decreasing chloropigment concentrations from canyon head (W0) towards the fan (W2), which is even more explicit in the other branch (figure $7 B$ ), could mean that the phytodetritus is supplied through the canyon. Other evidence for enrichment of the canyon sea floor compared to the fan and more so to the Goban Spur are the measurements on sediment community oxygen consumption and the concentrations of nucleic acid (figure 8). Dell'Anno et al. (1998) found high proportions of detrital (extra cellular) DNA in deep-sea sediments and question the use of DNA as biomass proxy. They argue that RNA is a better proxy for active microbial biomass and demonstrate this by a significant correlation between RNA and in situ sediment community oxygen consumption. RNA concentrations in the upper centimetre of the two canyon stations W0 and W1, i.e. $\sim 10$ and $\sim 7 \mu \mathrm{g} \mathrm{g}^{-1}$ respectively, were a factor two to three times higher than concentrations on the Goban Spur which varied between 2.5 and $4 \mu \mathrm{g} \mathrm{g}^{-1}$. Concurrently with the elevated RNA concentration at $\mathrm{W} 1$, we found an in situ sediment community oxygen consumption rate, i.e. $1.2 \mathrm{mmol} \mathrm{m}^{-2} \mathrm{day}^{-1}$, which was twice the value measured on station $\mathrm{O} 3$, which has a comparable water depth, and also twice the rate on the abyssal stations OE and W2. The values for these abyssal stations fit well into the annual range of sediment community oxygen consumption values measured by Witbaard et al. (2000) on the adjacent Porcupine abyssal plain at $4800 \mathrm{~m}$ depth. We have found no data to verify the in situ sediment community oxygen consumption rate of $0.64 \mathrm{mmol} \mathrm{m}^{-2} \mathrm{day}^{-1}$ found at the Goban Spur station $\mathrm{O} 3(3600 \mathrm{~m})$. Earlier data from station O3 concern values from shipboard incubations and these are 
commonly overestimates (see Duineveld et al., 1997). Additional evidence for a lower mineralization rate at $\mathrm{O} 3$ compared to $\mathrm{W} 1$ comes from the maximum oxygen penetration depths found in shipboard cores. Though the porewater profile is liable to changes during core retrieval, Lohse et al. (1998) found maximum penetration depth at station $\mathrm{O} 3$ both in situ as well as in shipboard cores to exceed $6 \mathrm{~cm}$ whereas at $\mathrm{W} 1$ we found penetration depths to be less than three centimetres.

Though there were no conspicuous differences in total macrofauna density between Whittard and Goban Spur stations, the macrobenthic biomass on the Whittard stations was higher (table II). Moreover, the macrofauna at the Whittard stations had a clearly distinctive character and particularly a higher percentage of filter-feeders (table III). At W0 these were mainly agglutinated foraminiferans (Saccorhiza), at W1 the tubicolous sabellid worms, and at W2 the Xenophyophora. None of the corresponding Goban Spur stations held these organisms in these densities (Flach et al., 1998). High densities of epi- or megafaunal foraminiferans have been reported off Cape Hatteras (Hecker, 1994) where the slope is enriched by coastally derived organic matter. Gage et al. (1995) found high proportions of agglutinated foraminiferans in the Setubal Canyon and the adjacent Tagus Abyssal Plain off Portugal. In combination with the high densities of metazoan organisms in the Setubal canyon, the authors infer that the canyon acts as a transport route for food particles from shallower areas. Most likely a similar explanation applies to the large number ( 10 individuals $\mathrm{m}^{-2}$ ) of particle-trapping xenophyophores that we found at W2 on the Whittard fan. Worldwide, xenophyophores appear to be especially abundant in regions of high surface productivity and on exposed topographic features like sea mounts, ridges, and also canyons, all of which offer conditions favourable for an enhanced suspended particle load (Tendal, 1972; Levin and Thomas, 1988). Likewise the high densities of sabellids at W1 suggest that on average the load of suspended organic particles passing over the canyon floor at W1 is higher than on any of the Goban Spur stations that we sampled in 1996.

The metazoan megafauna seen on video and caught in the trawl yielded no clear indication for differences in food supply between the Whittard and Goban Spur stations, since holothurians were the predominant type of organism at most stations. Many deep-sea holothurians thrive on nutritious particles in the uppermost sediment layer that some species are able to select with great efficiency
(Billett et al., 1988). We have no clue as to why Amperima (?) dominated on most stations including the Goban Spur and was absent from W1 where instead few large Benthodytes were found. Equally mystifying is the apparent shift in mobile megafauna between 1995 and 1996 (table V). Being dependent on the quality of surface particles (see above), this shift could be triggered by a change in the distribution of organic material on the top of the sediment. An example is the layer of fresh phytodetritus deposited in autumn 1995 at the foot of the continental slope, which appeared to be a food source for large holothurians like Pyschropotes (de Wilde et al., 1998). Apart from the cause, the mechanism of the change in the mesoscale distribution of these slow moving organisms is also not understood.

In conclusion, our cruise yielded strong indications for local enrichment of the canyon floor in comparison to the open slope (Goban Spur) possibly through transport through the canyon. This evidence consists of various sediment properties (organic carbon, phytopigments and nucleic acids) and of the community structure of the macrofauna. However, we were not able to find direct evidence in the form of enhanced near-bottom particle fluxes or bottom nepheloid layers. The lower part of all transmissometer profiles were straight without any trace of bottom nepheloid layers (figure 10). Furthermore, chloropigments in near-bottom water samples were all close to detection levels $\left(<1 \mathrm{ng} \mathrm{L}^{-1}\right)$. Also fluxes of

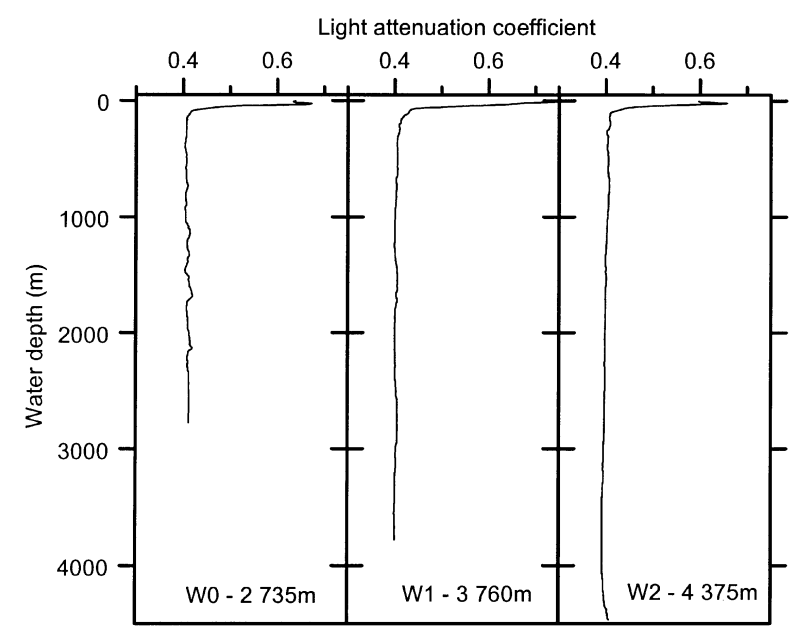

Figure 10. Water column profiles of light attenuation coefficient (maximum 1) in the canyon. None of the Whittard stations showed a near-bottom turbidity maximum. Measurements were made with Seatech $^{\mathrm{TM}}$ transmissometre mounted on a CTD. 
chloropigments in the Hydrobios traps on the benthic lander were roughly similar on the Whittard (W1, W2) and Goban Spur stations (O3, OE), i.e. between 8-12 $\mu \mathrm{g} \mathrm{m}^{-2}$ day $^{-1}$, which is the same range found in October 1993 and far below the levels found on Goban Spur in May 1994 (Duineveld et al., 1997). Apparently the processes causing enrichment of the canyon floor are variable in time as well as in space. The latter is clearly demonstrated by the samples from the east branch (figure $7 B$ ). Our preliminary data show that the role of canyons in exchange processes across the NW European continental margin cannot be neglected and should be investigated in more detail.

\section{Acknowledgements}

We are indebted to the crew of RV Pelagia and NIOZ technicians for their help during the cruise, and to A. Kok for the analysis of the nucleic acids. We especially want to thank D. Podaras who spent most of the time in the cold lab processing the core samples. We acknowledge the assistance of the Institute of Marine Biology in Crete and particularly Dr A. Tselepides for performing the $\mathrm{CHN}$ analyses.

\section{REFERENCES}

Anderson, R.F., Rowe, G.T., Kemp, P.F., Trumbore, S., Biscaye, P.E., 1994. Carbon budget for the mid-slope depocenter of the Middle Atlantic Bight. Deep-Sea Res. 41, 669-703.

Biscaye, P.E., Flagg, C.N., Falkowski, P.G., 1994. The shelf edge exchange processes experiment, SEEP-II: an introduction to hypotheses, results and conclusions. Deep-Sea Res. 41, 231-252.

Billett, D.S.M., Llewellyn, C., Watson, J., 1988. Are deep-sea holothurians selective feeders? In: Burke, R.D., Mladenov, P.V., Lambert, P., Parsey, R.L. (Eds.), Echinoderm biology: proceedings of the sixth international Echinoderm conference. Victoria. Balkema, Rotterdam, pp. 421-429.

Bloom, S.A., 1981. Similarity indices in community studies: potential pitfalls. Mar. Ecol. Prog. Ser. 5, 125-128.

de Bovée, F., Guidi, L.D., Soyer, J., 1990. Quantitative distribution of deep-sea meiobenthos in the northwestern Mediterranean (Gulf of Lions). Cont. Shelf Res. 10, 1123-1145.

Dell'Anno, A., Fabiano, M., Duineveld, G.C.A., Kok, A., Danovaro, R., 1998. Nucleic acid (DNA, RNA) quantification and RNA/DNA ratio determination in marine sediments: comparison of spectrophotometric, fluorometric, and high performance liquid chromatography methods and estimation of detrital DNA. Appl. Environm. Microbiol. 64, 3228-3245. de Wilde, P.A.W.J., Duineveld, G.C.A., Berghuis, E.M., Lavaleye, M.S.S., Kok, A., 1998. Late-summer mass deposition of gelatinous phytodetritus along the slope of the N.W. European Continental margin. Prog. Oceanogr. 42, 165-188.

Duineveld, G.C.A., Lavaleye, M.S.S., Berghuis, E.M., de Wilde, P.A.J.W., van der Weele, J., Kok, A., Batten, S.D., de Leeuw, J.W., 1997. Patterns of benthic fauna and benthic respiration on the Celtic continental margin in relation to the distribution of phytodetritus. Int. Rev. Gesamten Hydrobiol. 82, 395-424.

Flach, E., Heip, C., 1996. Vertical distribution of macrozoobenthos within the sediment on the continental slope of the Goban Spur (NE Atlantic). Mar. Ecol. Prog. Ser. 141, 55-66.

Flach, E., Lavaleye, M.S.S., de Stigter, H., Thompsen, L., 1998. Feeding types of the benthic community and particle transport across the continental slope of the Goban Spur. Prog. Oceanogr. 42, 209-232.

Gage, J.D., Lamont, P.A., Tyler, P.A., 1995. Deep-sea macrobenthic communities at contrasting sites off Portugal, preliminary results: 1 introduction and diversity comparisons. Int. Rev. Gesamten Hydrobiol. 80, 235-250.

Glud, R.N., Gundersen, J.K., Jorgensen, B.B., Revsbech, N.P., Schulz, H.D., 1994. Diffusive and total oxygen uptake of deep-sea sediments in the eastern South Atlantic Ocean: in situ and laboratory measurements. Deep-Sea Res. 41, 1767-1788.

Hecker, B., 1994. Unusual megafaunal assemblages on the continental slope off Cape Hatteras. Deep-Sea Res. 41, 809-834.

Heezen, B.C., Hollister, C.D., 1971. The face of the deep. Oxford University Press, New York.

Levin, L.A., Thomas, C.L., 1988. The ecology of Xenophyophores (Protista) on eastern Pacific seamounts. Deep-Sea Res. 35, 2003-2027.

Lohse, L., Helder, W., Epping, E.H.G., Balzer, W., 1998. Recycling of organic mater along a shelf-slope transect across the NW European Continental Margin (Goban Spur). Prog. Oceanogr. 42, 77-110.

Macquart-Moulin, C., Patriti, G., 1996. Accumulation of migratory micronekton crustaceans over the upper slope and submarine canyons of the northwestern Mediterranean. Deep-Sea Res. 43, 579-601.

Maurer, D., Robertson, G., Gerlinger, T., 1994. Comparison of community structure of soft-bottom macrobenthos of the Newport submarine canyon, California and the adjoining shelf. Int. Rev. Gesamten Hydrobiol. 79, 591-603.

Mauviel, A., Sibuet, M., 1985. Repartition of the animal traces and importance of the bioturbation. In: Laubier, L., Monniot, C. (Eds.), Deep-sea benthic communities from the Gulf of Biscay. Biogas cruise. Ifremer, Brest, pp. 157-173.

Monaco, A., Courp, T., Heussner, S., Carbonne, J., Fowler, S.W., Deniaux, B., 1990. Seasonality and composition of particulate fluxes during ECOMARGE-I, western Gulf of Lions. Cont. Shelf Res. 10, 959-987.

Reid, G.S., Hamilton, D., 1990. A reconnaissance survey of the Whittard Sea Fan, southwestern approaches, British Isles. Mar. Geol. 92, 69-86. 
Rowe, G.T., Polloni, P.T., Haedrich, R.L., 1982. The deep sea-benthos on the continental margin of the northwest Atlantic. Deep-Sea Res. 29, 257-278.

Rowe, G.T., 1983. Biomass and production of the deep-sea macrobenthos. In: Rowe, G.T. (Ed.), The Sea 8, Deep-Sea Biology. John Wiley and Sons, New York, pp. 97-121.

Rowe, G.T., Bolan, G.S., Phoe, W.C., Anderso, R.F., Biscay, P.E., 1994. Deep-sea floor respiration as an indication of lateral input of biogenic detritus from continental margins. Deep-Sea Res. 41, 657-668.

Sardà, F., Carte, J.E., Compan, J.B., 1994. Spatio-temporal variations in megabenthos abundance in three different habitats of the Catalan deep-sea (Western Mediterranean). Mar. Biol. 120, 211-219.

Smith, C.R., Hoover, D.J., Doan, S.E., Pope, R.H., Demaster, D.J., Dobbs, F.E., Altabet, M.A., 1996. Phytodetritus at the abyssal seafloor across $10^{\circ}$ of latitude in the central equatorial Pacific. Deep-Sea Res. 43, 1309-1338.

Soetaert, K., Heip, C., 1995. Nematode assemblages of deep-sea and shelf break sites in the North Atlantic and Mediterranean Sea. Mar. Ecol. Prog. Ser. 125, 171-183.

Soetaert, K., Heip, C., Vincx, M., 1991. The meiobenthos along a Mediterranean deep-sea transect off Clavi (Corsica) and in an adjacent canyon. Mar. Ecol. 12, 227-242.

Stephens, M.P., Kadko, D.C., Smith, C.R., Latasa, M., 1997. Chlorophyll $a$ and phaeopigments as tracers of labile organic carbon at the central equatorial Pacific seafloor. Geochim. Cosmochim. Acta 61, 4605-4619.

Tahey, T.M., Duineveld, G.C.A., Berghuis, E.M., de Wilde, P.A.W.J., 1996. Sediment O2 demand, density and biomass of the benthos and phytopigments along the Northwestern Adriatic coast: the extent of Po enrichment. Oceanol. Acta 19, 117-129.

Tendal, O., 1972. A monograph of the Xenophyophoria (Rhizopodea, Protozoa). Galathea Rep. 12, 7-103.

Vanaverbeke, J., Soetaert, K., Heip, C., Vanreusel, A., 1997. The metazoan meiobenthos along the continental slope of the Goban Spur (NE Atlantic). J. Sea Res. 38, 93-107.

Van Weering, T.C.E., McCave, I.N., Hall, I.R., 1998. Ocean Margin Exchange (OMEX I) benthic process study. Prog. Oceanogr. 42, $1-4$.

Vetter, E.W., Dayton, P.K., 1998. Macrofaunal communities within and adjacent to a detritus-rich submarine canyon system. Deep-Sea Res. 45, 25-54.

Walsh, J.J., Rowe, G.T., Iverson, R.L., McRoy, C.P., 1981. Biological export of shelf carbon: a neglected sink of the global $\mathrm{CO}_{2}$ cycle. Nature 291, 196-201.

Walsh, J.J., Biscaye, P.E., Csanady, G.T., 1988. The 1983-1984 Shelf edge exchange processes (SEEP)-I experiment: hypotheses and highlights. Cont. Shelf Res. 8, 435-456.

Witbaard, R., Duineveld, G.C.A., van der Weele, J., Berghuis, E.M., Reyss, J.P., 2000. The benthic response to the seasonal deposition of phytopigments at the Porcupine abyssal plain in the Northeast Atlantic. J. Sea Res. 43, 15-31.

Wollast, R., 1998. Evaluation and comparison of the global carbon cycle in the coastal zone and in the open ocean. In: Brink, K.H., Robinson, A.R. (Eds.), The sea: ideas and observations on progress in the study of the seas 10. John Wiley and Sons, New York, pp. 213-252. 